\title{
The Vanguardist Good Professor in Natural and Social Sciences
}

\author{
Renata Klafke $^{1}$, Marta Chaves Vasconcelos de Oliveira ${ }^{1} \&$ Jane Mendes Ferreira $^{1}$ \\ ${ }^{1}$ School of Management, Federal University of Parana, Curitiba, Brazil \\ Correspondence: Renata Klafke, School of Management, Federal University of Parana, Curitiba, ON., Av. \\ Lothario Meissner, 632 - Jardim Botanico, Brazil. E-mail: nena.klafke@gmail.com
}

Received: January 8, 2019 Accepted: January 30, 2019 Online Published: February 25, 2019

doi:10.5539/jel.v8n2p47

URL: https://doi.org/10.5539/jel.v8n2p47

\begin{abstract}
The aim of this study is to identify what features make good professors in the social and natural sciences. Are these qualities the same? Through gathering data from undergraduate business and engineering students, we searched for educator's characteristics considered positive or ideal for the learning process. This research used primary data resources collected through online survey. Technical analysis of the content was used for interpretation of the results. Students from the social and natural sciences have similar points of view and expectations about towards their professors. Scholars believe docents should be more comprehensive and prepare students for the market, and not use the classes to expose their (students') ignorance, lack of mastery of the subject, difficulties, nor poke fun at them. Fortunately, these behaviors are not common place, but are known to exist, and represent a display of a remarkably unprofessional, egotistical, and arrogant conduct by the instructor. Social science professors are often more communicative and show more empathy, while natural science professors are more technicians and follow the syllabus, texts and material in a more rigid manner.

This research is relevant for docents to reflect on their teaching persona and about the importance of self-awareness during their Master and Doctor programs. It is equally important for educators to see themselves through their students' eyes, so they can endlessly strengthen their own practice.
\end{abstract}

Keywords: social science, natural science, good professor, education

\section{Introduction}

Every time a school year is about to come to a close, Professors' evaluations by students must be carried out by most Universities. According to Luckesi (2011), the act of evaluating the learning process in Universities is to make it more productive and satisfactory, as Universities are no longer just formation centers, but institutions that meet the basic principles of modernity, whether in relation to labor relations or in the provision of services to Society (Tenório \& De Andrade, 2009). And, in this case, good professors are comfortable with and practice this new concept.

The learning evaluation should be understood as an ongoing process. It is the principle of a checking point, that is, if professors are well prepared for the job, if the methodologies used are attractive, among other things. From the evaluation comes the analysis and decision-making on "what to do", so the evaluation should strengthen the efficacy of the universities' systems. As Lowman (1995) states, the learning evaluation is part of the education analysis, and its quality is a result of professor's ability to create 'intellectual stimulation' and 'interpersonal empathy' with students.

In higher education, education's evaluation has been stimulated by educational governments policies with the creation of national evaluation agencies in order to control the expansion and diversification of this level of education (Tenório \& De Andrade, 2009). In terms of training and development, some institutes are specialized in professors' qualification and development. And certain standards are provided in written form which the professor must read and sign before being placed in their permanent record. Apart from them, there are still the traditional internships (that last only a few weeks or months) during masters and doctoral courses, which aspiring professors (students) must take. All these preparations intend to enable professors to have a more positive approach inside the classes; become better professionals, as most of the time they dominate only the theory or practical field, since they are not provided with the proper pedagogical foundation for their role inside the classroom (Hernandes, Peleis, \& Barbalho, 2006; Cruz et al., 2017). The most known pedagogical foundations are Behaviourism (any learning activity is a response to an impulse), Cognitivists (where memory and 
motivation are part of comprehending things, actions, reality as a such, so, learning is an internal process) and, most recent, the Programmed Teaching (which was based on the new interpretation of information content concept; each information may be chopped up into very small bits) (Hubackova, 2014). In this sense, the teaching process of any Science becomes a very difficult task.

In this study we investigate students' perceptions about social and natural science professors. The objective is to compare "what is a good professor" for students of these two different areas. This study will also indicate which features the new generation of students (millennials) appreciate in a docent for their learning process. This research is composed of four sections, in which the first one will briefly address the Professors' characteristics and education/formation of two different areas: natural sciences and social sciences. The second part describes the methodological procedures of the research. The third elucidates the results of this investigation and, finally, the considerations are presented as reference points for future research.

\section{Theory Background}

\subsection{The Good Professor}

Professors are no longer mere knowledge transmitters, instead, they lead students to build their values, attitudes and skills which will allow them to grow as productive and well-balanced citizens. In this way, students can change the future, playing a constructive role in society (Wheatly, 1991). According to Freire (1996) a good professor is the learning mediator. Someone who is responsible to favoring the reflexive and investigative posture. In this way the professor will help students to build autonomy of thought, expanding the possibility of social participation and mental development (Freire, 1996; Stefanou et al., 2008).

A constant challenge any professor must face is to keep students interested in their lectures, when there are so many technological changes and devices that compete for the student's attention (McCoy, 2016). In this sense, good professors must be aware about what is expected from them; offering an interactive class. Times have changed and as a result, the traditional way of teaching is obsolete, and modifications have long been needed. Already in 1994, when the technical revolution was basically beginning, that is, more and more technologies were appearing, Libanêo (1994) had already said that the act of teaching cannot be perceived as something passive and mechanical (repetition for 'deep memorizing' of content) and, therefore, require constant readjustments to be more effective and attract student's attention.

Until the shift from analogue electronic technology to digital electronics digital revolution (in the 70s), the behavioristic influenced the school learning by rule orientation. In the past, most of the time, students were mainly memorizing facts (Wheatly, 1991). According to Park and Choi (2014), traditional classes convey an image of educational philosophy about teaching and learning, which includes a standard lecture hall, with uncomfortable seats with all students facing the lecterns, while they "inject content into students' brains". This rote style of learning allows the students to regurgitate the material depending on the testing method. If a professor uses this method with a selection of answers which a student may choose from, it is necessary to continue with this method. Switching from select the correct answer to a fill in the blank type test causes problems for the students. They have been trained to take the test in one way, but when it is changed, often the student's mind goes "blank" not knowing the proper term when presented with no options. One student in particular reported that he had received all "A' $\mathrm{s}$ " in all of his courses previously, but when faced with a different testing method, he received a lower score on the test and as a result, received a "B" in the course. This one test had serious consequences. Instead of having a 4.0 average grade, the highest available for all coursework, he received a 3.7 average, firstly because the method of testing had changed and secondly this particular test was 30\% of the course grade which dropped his semester average in a negative way and his overall grade point average. This particular professor was not aware of the difference changing the testing method would make, but he was also one of those who had been giving the same. Lectures for 20 years. He was out of touch with the changing realities and neglected his own professional development.

With a better understanding about the complexity of human psychology and the environmental factors (in the 80 s) influencing the learning capacity, the cognitive science approach initiated the emphasis on the role and importance of a Professors social abilities and class design; cooperative and active learning was introduced (Park \& Choi, 2014). As a critical professor, he/she should be predisposed to change, to learn new methods and to accept the different in order to become a better docent. Nothing in the teaching experience must necessarily be repeated (Freire, 1996). With student's recognition for their effort, professors feel satisfied and motivated (Lowman, 1995; 2004). Although some docents began to review their didactics with the digital revolution and with the introduction of the internet (90s), a somewhat surprising number continue to resist. One possible reason 
for the lack of change towards student-centered pedagogy, given the widespread provision of computers in classroom, could be due to the beliefs that professors hold (Teo et al., 2008).

At present it is deemed essential to provide students with a rational understanding of the world, with what happens around them: their reality. This leads them to a position of life free of prejudices and a more appropriate position regarding where they live and the environment they occupy (Freire, 1996). For the pedagogue, an education based on the accumulation of information, where students should incorporate certain knowledge (decontextualized from their experience), would be a serious problem for learning.

Success in academic life, pertaining to the way a student views the learning process, depends primarily on the mastery of some fundamental cognitive skills. These include-reading, writing, critical thinking and oral presentation. According to McNamara (2009), Doctorates (or PHDs) rarely teach such skills to students. In general, they take it for granted, as they assume that everybody has already acquired these skills in high school. The reality is that most of first-year students lack academic reading skills, especially reading as the university reading level and quantity; they greatly differ from the reading in High School. For this reason, some scholars (Frederick, 1999; Renner, 1993) criticize the sudden change that occurs in educational institutions, that is, the way they are taught in high school, and how they are carried out in universities. And therefore, a social approach and a closer relationship (professor and student) especially in the first year at the University, might help students to have a more favorable experience and impression at the beginning of the course (Bennett, 2003). One result of this drastic change in environment and learning atmosphere is often indicated in the higher than expected drop-out rate during the first year when attending a university without due preparation.

The belief that emotions and social relations influence professor's better development in classes, this study is ruled by the Lowman (2004) model that defines the "good professor". According to Lowman's model (2004) the education's quality is a result of professor's ability to create 'intellectual stimulation' and 'interpersonal empathy' with students. The author defends the assumption that the profile of the good professor can be defined by six features (or attributes) and excellent professors are distinguished by at least two dimensions of the following: (a) knowledge, planning and didactics, (b) technological capacity, (c) relationship with students, (d) personal attributes, (e) motivation, and (f) level of demand/exigency, although some authors consider other general variables, such as classroom layout or culture as key elements that support students' learning (Park \& Choi, 2014; Wlodkowski \& Ginsberg, 2018). The first 3 attributes (a, b \& f) mentioned above belong to the intellectual stimulus. The other attributes (c, d \& e) belong to the interpersonal empathy category. Intellectual stimulus is related to the way in which professors explain the content of their disciplines, which means, how clear the content is and how he/she involves a student's ability to think. Yet, Interpersonal empathy is concerned with social relations, which means, how interested is the professor in the students' experiences and histories, and his or her ability to comprehend emotions (Lowen, 2004; Cuseo, 2018).

\subsection{The Social Science Professor}

It is not a new concept that social science schools should concentrate their efforts on developing courses according to a society's needs, providing intellectual leadership for students (Pierson, 1959). Business administration depends quite a lot on other social sciences, such as sociology, economy and psychology, just to cite a few, that demand a holistic knowledge and that view is obligatory. In this sense, a professor's qualifications are essential not only for the business school's success, but as well for the scholar's development.

Farashahi and Tajeddin (2018) identified in their research in Canada, that the real world of business is far ahead of the academic knowledge and skills taught in the business education. They stress that Business education has evolved at a much slower pace than the actual business field/market, and one possibility is because Universities are recruiting more academically trained faculty members with doctoral degrees and scientific qualifications, and as a result these educators are not really interested in becoming better professors, nor within the market, but instead, to sit in their office trying to find a theory gap (Whetten, 2007; Farashahi \& Tajeddin, 2018). In quite a number of situations, Doctoral level professors do not feel the need to be "babysitters" for their students or teach them what they should have already learned in their previous course work. This poses a difficult problem for both the students and professor. This is critical if the student is to receive the education he or she expects and should be specifically addressed by the administration and all department heads.

Nogueira et al. (2012) studied the good professor profile in a social science course. The authors found out that the most valuable features (students' perceptions) were: mastery of content, ability to explain and the link between theory and practice. The characteristics less relevant were related to the physical characteristics, such as: physical beauty and having a pleasant voice. Another investigation (Soster, 2011) with business administration professors, that also aimed to investigate the characteristics that shape a good social science docent, found that 
students appreciate professionals that are up to date with technological advances in multiple areas, that are intelligent, flexible, possess the knowledge and can explain in a clear, simple and objective manner. Empathy becomes also very important as it facilitates the learning process. In addition, the study stressed that PhDs should be able to stablish a relationship of trust with the student and be well-humored.

In a self-critical and reflective paper about becoming a good social science professor, Wisneski (2013) elucidates some key aspects and problems that challenges business professors from his years of management consultation within industry and as a university docent. According to him, as industry professionals, they are aware of the performance measures and rewards for the appropriate technical skills. So, the success is dependent upon workers ability to meet these demands. In general, if professors are not adequately and objectively evaluated, and receive recognition professionally or financially, then what could possibly motivate them?

Wineski (2013) points out that academicians tend to view their activities as individualized enterprises. Many docents view their teaching materials as proprietary knowledge assets. Academia is a field in which the creation of knowledge capital is protected, and highly guarded, instead of being shared. Other issues about the collective learning are expressed in the article, such as the passive learning method and the usage of old and not interesting methodologies.

\subsection{The Natural Science Professor}

Engineering is about knowledge and practice. Mathematics and other similar sciences are viewed as a codified body of knowledge to be taught. Most educational systems in every culture operate from this perspective (Wheatly, 1991). And until some decades ago, many engineering docents were professionals who worked in the labor market and, in parallel, practiced teaching as a "Hobby", like an altruistic spirit, among others (Pinto \& Oliveira, 2012).

Even though unemployment tends to be low in this field, students are very dissatisfied with the knowledge and skills acquired during their university education (Guerrero et al., 2012), and one reason might be that Masters and $\mathrm{PhD}$ courses which are expected to qualify an Engineering Professor are not necessarily concerned with qualifying them didactically, but only technically (Pinto \& Oliveira, 2012).

According to research (Loder, 2005), the good engineering professor should:

Be an expert in his/her field of knowledge;

Be respectful in his/her relationship with the student;

Be organized;

Be available to the student, showing capacity for dialogue and interaction;

Be consistent in its assessment;

Be committed to his/her teaching;

Be motivational;

Be a classroom authority

Most of these characteristics match the ones that are expected in a good professor, as shown in 2.1 section.

Surveys with graduates and employers have revealed that Engineering education has some learning/teaching problems such as theoretical approach to problem solving, insufficient understanding of real-life problems, and poor communication skills (Pollard et al., 2015). In order to solve these needs, Aalborg University (in Denmark) created the Global Systems Design. The program is successful due to the involvement of companies and the use of real-world cases throughout the program (Kádárová et al., 2014). With this foundation, educators hope to provide an environment for applied problem solving, which allow students apply their classroom knowledge.

\section{Method}

In this section the procedures used to achieve the aim proposed in this work are described. The research focus is qualitative. According to Yin (2011), through qualitative research it is possible to interpret perspectives considering real-life scenarios. In this paper, the aim is to understand students of Natural and Social Sciences regarding docent's 'practice'. The research can be classified as exploratory and descriptive.

This study used primary data resources collected through online survey, composed of nine questions. The first seven referring to the student's profile and the last two questioning student's perspective regarding some teaching features. On October the 1st the survey was sent to two coordinators of the Natural Science courses and Social Science courses of the Technological Federal University of Parana (UTFPR) in the south of Brazil. The 
coordinators forwarded the survey to students via email. The survey was opened to respond from October the 1st to October 15th. No specific criteria were used for the student's selection. The sample of this paper is composed of 32 students of the Social Science courses and 66 students of the Natural Science courses. Considering the number of the social science respondents, 50\% are male and the others 50\% are female. Most of the students live in Curitiba City (capital) and 16\% live in Pato Branco City (interior), a very few students live in the metropolitan region of Curitiba. Now, considering the Natural Science profile, $47 \%$ of the respondents are male and $53 \%$ female. Of the 66 survey respondents almost 97\% live in Curitiba City and 3\% in Colombo City.

Technical analysis of content was used for interpretation of the results. Students' responses were coded and regrouped into categories according to this research objectives. Based on the theoretical framework used, it was possible to create the analytical categories.

\section{Results}

\subsection{Social Science and Natural Science Student's Profiles}

Figure 1 shows the number of respondents according to the year and semester that they had begun the course. It is possible to see that 15 students began the course in 2018, and the students who began the course in 2012,2013, 2014, 2015 and 2016 have studied more than 4 semesters, that is, already studied more than half of the course.

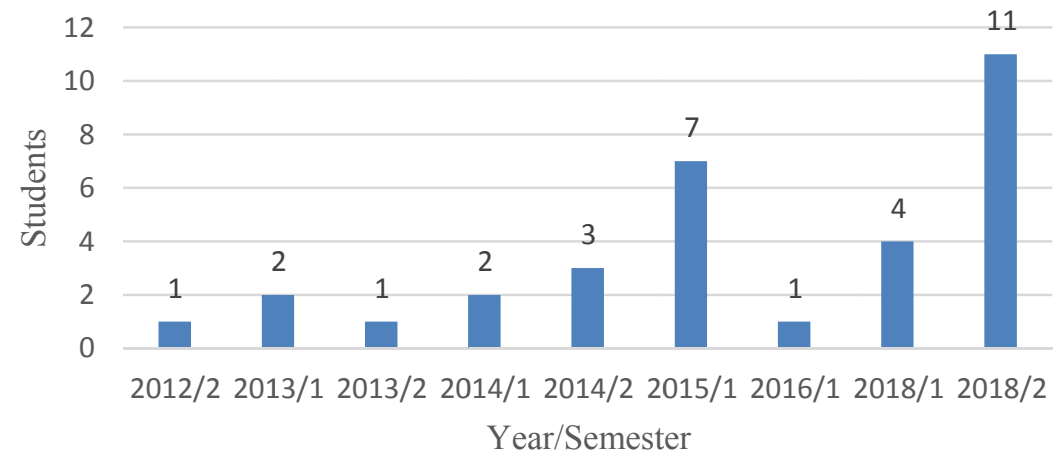

Figure 1. Distribution of the social science students, according to their year and semester course

Source: created by the authors, 2018 .

In Figure 2, it can be observed the student's age, and most of them (60\%) are between 20 and 24 years old. However, in the Natural Science the maximum age range is between 30 and 34 years, while in the Social Science students are mainly in the 45 to 49 years group.

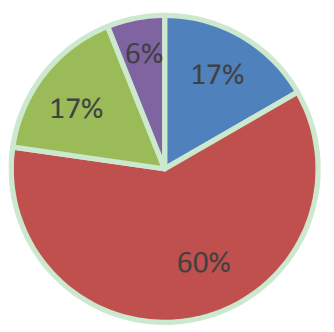

घ 15 to $19 \square 20$ to $24 \square 25$ to $29 \quad 30$ to 34

Figure 2. Age group distribution of the natural science students

Source: created by the authors, 2018 . 
Usually, Natural Science courses are full time, which means that students have classes during the day. In Figure 3 , it is possible to see the number of respondents, according to the year and semester that began the course. 22 students $(33 \%)$ have not yet completed half of the course.

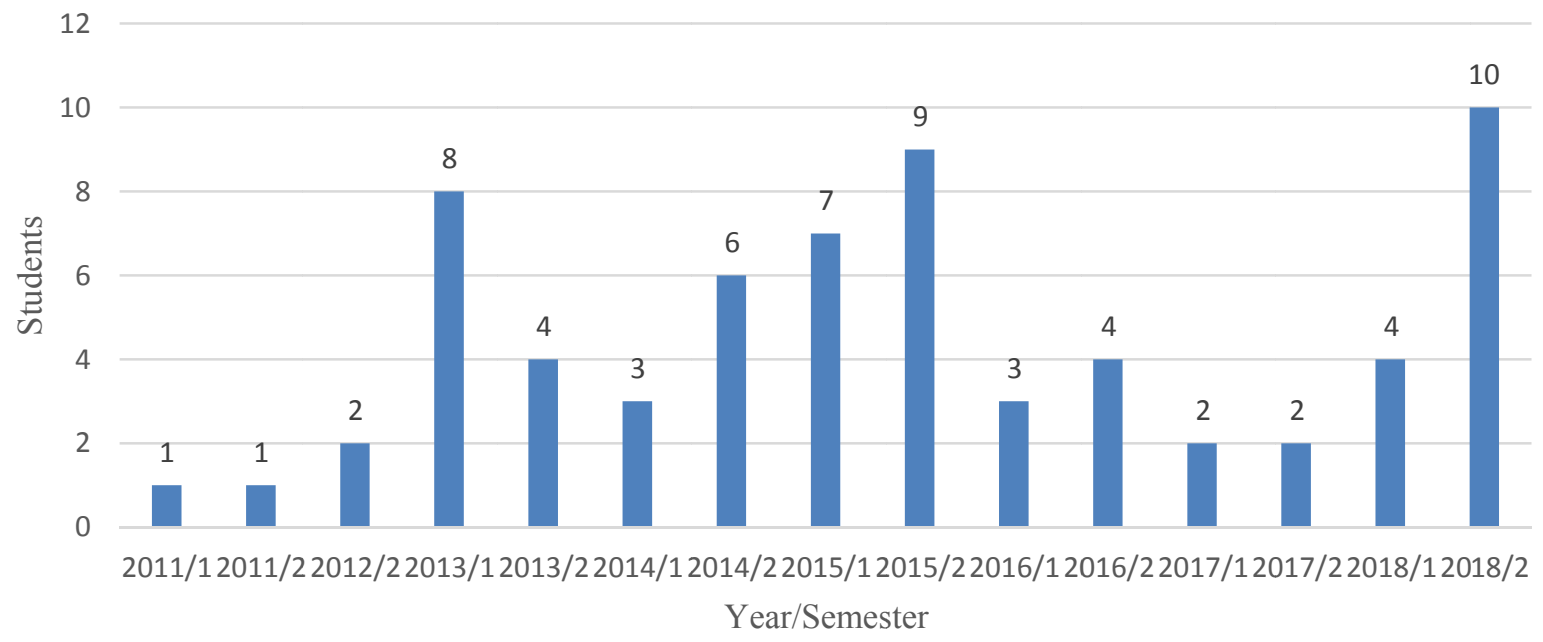

Figure 3. Distribution of the natural science's students, according to their year and semester course

Source: created by the authors, 2018 .

\subsection{Student's Perspective Regarding "the Good Professor" in the Natural Science and Social Science}

Data analysis was developed in a deductive way based on the theoretical reference presented. In the end of the analysis two final categories were identified that are related to the teaching practice. These categories were: (I) Interpersonal Empathy and (II) Intellectual Stimulus.

Category (I) - Interpersonal Empathy — is described according to Lowman's (1995) understanding. This category is composed of the following second order themes: (A) Relationship with students, (B) Personal Characteristics and $(\mathrm{C})$ Motivation.

The second order theme (A) - Relationship with students - explain how interaction between teachers and students happens, how teachers deal with students, and how professors interact with them during the classes. In this research, some students emphasized that the relationship with the professor is not very pleasant and one of the reasons is due to docent's nonconformities. When asked "What did your worst undergraduate professor to you perceive he/she the worst?" One of the students (social science-SS) said:

"He/She is arrogant, he/she does not like being asked. It made me doubt about his/her intellectual ability, so I lost interest in his/her class and ended up looking for studying alone, which is natural, but I don't tolerate people who are intolerant, prejudiced and offensive" (Student, 10).

It may be noted that some students consider that some professors are responsible for rending problematic relationship. It happens when professors are insensitive or show no interest in the learning process. Student 32 SS answered: "Professor with lack of empathy". It is noticed that the relation can be impaired when a professor doesn't put himself in the student's shoes. Student 27-SS answered: "He/She doesn't listen to us. He/She always feels right, without admitting mistakes. He or She cannot explain the subject, always look at us as if we had the same level of understanding as he/she does." This fact was mentioned not only from beginners, but as well as with students who began in previous years.

The above situation also happens in the natural science courses; however, this can be observed with more emphasis with students who are already finishing the course. Student 8 (Natural Science-NS) answered: "Professors think we knew everything and sometimes humiliated us." In some cases, students mentioned prejudicial issues, as well as humiliation in front of the whole class when the professor was questioned. Student 21-NS said: "He/She doesn't listen to us, he/she thinks that is funny when students have doubts, he/she doesn't teach properly, and some male professors are sexist." Another female student said: "Arrogant, he/she did not 
teach clearly and objectively, and made sexist jokes. Classes were not planned, and the tests had contents that were not taught."

Students would like to be understood. Students want professors to care about their learning stages. Some students felt intimidated into not asking questions, because the docent didn't like to be questioned and this fact consequently ended up restricting part of the learning. According to Freire (1979), the professor isn't superior in comparison to students in the classroom. He/she shouldn't consider that he/she lectures a group of ignorant people but should assume a humble position of one who communicates knowledge. According to Lowman (2004), professors need to be attentive to students under pressure, this means that they must adapt the class to the student's reality, that is, they should cite examples that are compatible with student's environment, and respect such issues like religion, gender, physical disability, race and sexual orientation. When asked "What did your best undergraduate professor to you to perceive he/she the best?" "Student 23-NS said: "He/She cared about the life behind each student and cared about the teaching method, adjusting it when necessary." Another student stated: "He/She could see student's deficiency" (Student 41-NS).

The concept (B) - Personal Characteristics - presents professor's profile, that is, how professor behaves in front of the students. Personal and professional attributes are presented in this second order category. In the social science, it is possible to note that students associate positive characteristics such as: dedication, sympathy and empathy. When asked: "What did your best undergraduate professor do to you to perceive he/she the best?" One of the students said: "He/She is spontaneous, friendly and gives good examples to us" (Student 7-SS). In the natural science the situation is a lot like the students of social science. One of the students replied "He/She is excited to teach, explains well, has knowledge" (Student 13-NS). According to Lowman (2004), in order to teach a good lesson, professor should be guided by students, that is, to continuously observe students' reactions about the class, recognizing and modifying their approach when necessary.

Concept (C) - Motivation — presents how professors motivate students. In this category (also of second order) it is highlighted the ways in which professor interact and boost students' learning. Also, it is about the ways in which professors interact (correlate) with other undergraduate courses, with the labor market and society. One of the students of the social science answered: "He/She explained the subjects in order to encourage the interest in the subject and to expand our knowledge beyond the boundaries of the discipline" (Student 26-SS). Another replied: $\mathrm{He} / \mathrm{She}$ connected the discipline with the society, and I felt part of the process (Student 10-SS).

The motivation a professor has towards students was perceived throughout the course. This fact can be observed in the social and natural sciences. Something that motivates scholars is when the relationship between them and the professor is adequate, that is, when the professor corresponds with students' expectations in relation to the dynamics of the classes and to students' learning. Student 60-NS said: "He/She was interested and dedicated to us and to the discipline. He/She was happy to minister something that was possible to make us comprehend".

Category (II) - Intellectual Empathy - is explained by Lowen (1995) and Wlodkowski and Ginsberg (2018). This category is composed of: (A) Knowledge, Planning and Didactics, (B) Technological Capability and (C) Level of Requirement.

The second order category (A) Knowledge, Planning and Didactics presents how professors prepare their classes They highlight professor's level of knowledge, organization and discipline in relation to the class time. This category also highlights the ways in which professor presents the contents of the discipline, as well as the dynamics used during the classes to promote interaction and debates. In the social science students, it can be observed that they appreciate a docent with knowledge, particularly when professors review the subject of the previous classes. When asked: "What did your best undergraduate professor do to you to perceive he/she the best?" One student said:

The classes are prepared in advance, he/she writes on the blackboard (during the whole semester, he/she used the projector around 3 times and didn't limit the teaching performance). He/She encouraged students to complement the knowledge and, in the beginning of every class, a 5 minutes review was done (Student, $5-\mathrm{SS})$.

Another point to highlight is the content taught in the classroom with the job market. Student 21-SS said: "He/She used up-to-date methods of class interaction, without slides or dull medias, linking the subject to the actuality/reality of the job market." Another student said: "He/She demonstrated theoretical and practical knowledge, linking each other with real cases, beyond self-confidence and differentiated methodology" (Student 6-SS). Student 15-SS said: "He/She provided case discussion and Project Learning Based." Thus, it can be observed that students value the knowledge professor holds regarding the discipline, as well as classes with different methodology. There are students who pointed out the need to correlate theoretical content to practice, 
these students are mostly students who are already finishing their courses (social science). According to Lowman (2004), a professor who conducts a good class looks for concise ways to present and illustrate the content taught, always reviewing the previous class.

Natural science students had similar answers. They believe professor's knowledge, as well as practical examples cases two very important characteristics. Considering the knowledge, planning and didactics, when asked "What did your best undergraduate professor do to you to perceive he/she the best?" Student 5-NS answered: "He/She teaches the subject according to the teaching plan, always makes all students understand the subject." Student 11-NS said: "He/She explained theoretically and practically at the same time." Student 18-NS said: "The content was taught in an organized way." Students also stressed the importance of the dynamics of the classes. One of the them said: "He/She gave good explanations, demonstrated mastery over the subject and knew how to teach the content interactively" (Student 25-NS). Student 29 added: "Simple and objective explanations, several examples of application of the content, good humor, solicitude, and constant revisions." Another student answered: "He/She had didactics and interaction with us, always requested our feedback on the understanding." (Student 56-NS). As in the social science, it was possible to see that students who are finishing the course emphasized the importance of the relationship between theory and practical examples. According to Lowman (2004), professors should plan his/her classes in advance and look for continuous evaluation about his job, because through the feedbacks it is possible to identify the weaknesses and correct them, as well as to continue improving.

Concept (B) - Technological Capability—presents how professors use communication and information technologies to help them during the classes. However, such resources can be used either positively or negatively, depending on the context and how professors use such technologies. It's possible to note that students of the social science don't like when professors use slides throughout the class, because look like that they do not know the content. When asked: "What did your worst undergraduate professor do to you to perceive he/she the worst?" One of the students reported: "He/She presented the content always on a slide, in other words, he/she sit on his/her chair and read the slide that was prepared 5 years ago" (Student 30-SS). The same fact can be seen in the Natural Science students. Student 2-NS said: "He/She didn't present any dynamic and just read the slides." Student 16-NS said: "He/She only read slide, didn't know to answer our questions and didn't have didactic." This criticism regarding professor's posture in just reading slideshows during the classes was observed in both sciences and specially with students who are finishing the course. According to Lowman (2004), a bad class can be characterized when professors do not change or adapt their teaching method and class to students 'reality, as well as when they do not change wrong attitudes that have been carried out for some time'. Lowman (2004) says professors should use audiovisual resources in order to retain student's attention.

Category (C) - Requirement Level—presents the ways professors evaluate students. It is about students' knowledge evaluation. Social Science students answered that bad professors have inconsistent evaluation way. One student mentioned: "He/She overloaded the students with reading papers and instigated limited discussion of the texts" (Student 26-SS). This fact was also observed, but in lower level, in the natural sciences; however, professors' demands were much more emphatic with Natural Science students than with the social ones. Student 46-NS said: "He/She didn't apply other types of evaluation; just tests, and only difficult tests." Student 27-NS reported:

"He/She acted as if that discipline was unique or the most important of the whole course. He/She asked from us a lot, as if we were robots. He/She was rude. More than the half of the professors consider students lazy, when in fact we are only afraid to ask."

Therefore, it may be observed that students disapprove professors who make an impartial test. Professors must be cohesive in his/her evaluation form, he/she must lead the class in a way that students will increasingly seek the search for knowledge. The purpose of the evaluation is to provide information about the students' performance against the expected objectives, so the evaluation form must be consistent with the content taught. It should be stressed that there are several assessment techniques and instruments which are essential for a committed evaluation about the quality of students' learning (Souza \& Vieira, 2012).

\section{Conclusion}

This work presented student's perceptions about what features make a good and bad professor. It aimed to find out similarities and differences among students from 2 different areas; Social and Natural Sciences.

According to our results, students, doesn't matter the science, would like to be understood and expect professors to care about their learning process; to be really interested in them. Some students believe that some professors make their relationship difficult, especially when they are insensitive or show no interest in their reality. 
According to Lowman (2004), in order to teach a good lesson, a professor should be guided by students, which means to continuously observe their reactions and modify their approach when necessary. Also, Neuroscience shows that the development of the brain stems from the integration between the body and the social environment. The educator needs to potentiate this interaction.

Among some positives feature students' value in a docent are the knowledge hold and the usage of different methodology. It is necessary to make an effort to bring to the pedagogical field the innovations introduced in the last decades. Even though it wasn't the focus of the study, it was noticed that Natural Science professors show some kind of sexist prejudice, and perhaps due to the fact that most of the professors who that teach the course are male.

With this work, we hope that educators see themselves through their students' eyes, so they can endlessly strengthen their own practice. This is often done during the last day of class upon completion of the final examination or in a situation in which the student's final paper, which can make up to $1 / 3$ of his or grade for the term, is still under consideration and not returned to the student. And in many cases the final paper is not returned to the student at all, which does not allow the scholar to learn from mistakes or receive praise for his or her work. The problem with this assessment method that is rarely accurate because it is hand written and the student may feel intimidated, fear that since his or her comments will identify them to the instructor. Or in many cases with the final exam completed they write little of any constructive criticism or comments on the teaching methods.

\section{Acknowledgments}

This research was developed with funding from a research grant offered by Coordination of Improvement of Higher-Level Personnel (CAPES).

\section{References}

Bennett, R. (2003). Determinants of undergraduate student dropout rates in a university business studies department. Journal of Further and Higher Education, 27(2), 123-141. https://doi.org/10.1080/030987703200065154

Cruz, A. P. C. D., Quintana, A. C., Machado, D. G., Czarneski, F. R., \& Lucas, L. D. O. (2017). Quais atributos definem um bom professor? Percepção de alunos de cursos de ciências contábeis ofertados no Brasil e em Portugal. Revista Ambiente Contábil-Universidade Federal do Rio Grande do Norte, 9(1), 163-184.

Cuseo, J. (2018). Student-Faculty Engagement. New Directions for Teaching and Learning, 154, 87-97. https://doi.org/10.1002/t1.20294

Ertmer, P. (2005). Teacher pedagogical beliefs: The final frontier in our quest for technology integration? Educational Technology, Research and Development, 53(4), 25-39. https://doi.org/10.1007/BF02504683

Farashahi, M., \& Tajeddin, M. (2018). Effectiveness of teaching methods in business education: A comparison study on the learning outcomes of lectures, case studies and simulations. The International Journal of Management Education, 16(1), 131-142. https://doi.org/10.1016/j.jime.2018.01.003

FrederickK, P. J. (1999). The Lively Lecture: Eight Variations. In B. A. Pescosolido \& R. Aminzade (Eds.), Fieldguide for Teaching in a New Century (pp. 62-71). Thousand Oaks, CA: Pine Forge Press.

Freire, P. (1996). Pedagogia da autonomia: saberes necessários à prática docente (p. 90). São Paulo: Paz e Terra.

Greatbatch, D., \& Holland, J. (2016). Teaching quality in Higher Education: Literature review and qualitative research.

Guerrero Chanduví, D. A., De los Ríos, I., \& Palma Lama, F. M. (2012). Higher education in industrial engineering in Peru: towards a new model based on skills (vol. 46, pp. 1570-1580). In 4th World Conference on Educational Sciences. WCES-2012, Barcelona, Espa-a. 02 de febrero de 2012. Universidad de Piura.

Hernandes, D. C. R., Peleis, I. R., \& Barbalho, V. F. (2006). O professor de contabilidade: habilidades e competências. In Saraiva (Ed.), Didática do ensino da contabilidade: aplicável à outros cursos superiores (1st ed., pp. 61-119). São Paulo.

Hubackova, S. (2014). Pedagogical foundation of eLearning. Procedia-Social and Behavioral Sciences, 131, 24 28. https://doi.org/10.1016/j.sbspro.2014.04.073 
Kádárová, J., Kováč, J., Durkáčová, M., \& Kádár, G. (2014). Education in Industrial Engineering in Slovakia. Procedia-Social and Behavioral Sciences, 143, 157-162. https://doi.org/10.1016/j.sbspro.2014.07.379

Libâneo, J. C. (1994). O processo de ensino na escola (pp. 77-118). São Paulo: Cortez.

Loder, L. L. (2005). O bom professor de engenharia: visão dos alunos versus visão dos professoresaproximações e distanciamentos. In XXXIII Congresso Brasileiro de Ensino de Engenharia.

Lowman, J. (2004). Dominando as Técnicas de Ensino. São Paulo: Atlas.

Lowman, J. (1995). Mastering the Techniques of Teaching. San Francisco: Jossey-Bass.

Luckesi, C. C. (2011). Avaliação da Aprendizagem Componente do ato pedagógico. Cortez Editora.

McCoy, B. R. (2016). Digital distractions in the classroom phase II: Student classroom use of digital devices for non-class related purposes.

McNamara, D. S. (2009). The importance of teaching reading strategies. Perspectives on Language and Literacy, 35(2), 34.

Nogueira, D. R., Nova, S. P. D. C. C., \& Carvalho, R. C. O. (2012). O bom professor na perspectiva da geração Y: uma análise sob a percepção dos discentes de Ciências Contábeis. Enfoque: reflexão contábil, 31(3), 37 52.

Park, E. L., \& Choi, B. K. (2014). Transformation of classroom spaces: Traditional versus active learning classroom in colleges. Higher Education, 68(5), 749-771. https://doi.org/10.1007/s10734-014-9742-0

Pierson, F. C. (1959). The education of American businessmen. The Journal of Business Education, 35(3), 114 117. https://doi.org/10.1080/08832323.1959.10116244

Pinto, D. P., \& Oliveira V. F. D. (2012). Reflexões sobre a prática do engenheiro-professor. In Congresso Brasileiro de Educação em Engenharia (vol. 40, pp. 1-11).

Pollard, E., Hirsh, W., Williams, M., Jonathan, B., Marvell, R., Tassinari, A., \& Ball, C. (2015). Understanding employers' graduate recruitment and selection practices (p. 231). BIS Research Paper.

Stefanou, C. R., Perencevich, K. C., DiCintio, M., \& Turner, J. C. (2004). Supporting autonomy in the classroom: Ways teachers encourage student decision making and ownership. Educational Psychologist, 39(2), 97-110. https://doi.org/10.1207/s15326985ep3902_2

Soster, T. S. (2011). O uso da tecnologia da informação e comunicação no processo de ensino e aprendizagem: estudo de um curso superior na área de administração (Doctoral dissertation).

Souza, M. A., \& Vieira, A. M. D. P. (2012). Metodologia do Ensino Superior: avaliação na educação superior. Brasília: PNAP. Avaliação do ensino superior.

Tenório, R. M., \& de Andrade, M. A. B. (2009). A avaliação da educação superior no Brasil: desafios e perspectivas. Avaliação Educacional desatando e reatando nós, 31 .

Teo, T., Chai, C. S., Hung, D., \& Lee, C. B. (2008). Beliefs about teaching and uses of technology among pre service teachers. Asia-Pacific Journal of Teacher Education, 36(2), 163-174. https://doi.org/10.1080/13598660801971641

Wheatley, G. H. (1991). Constructivist perspectives on science and mathematics learning. Science Education, 75(1), 9-21. https://doi.org/10.1002/sce.3730750103

Whetten, D. A. (2007). Principles of effective course design: What I wish I had known about learning-centered teaching 30 years ago. Journal of Management Education, 31(3), 339-357. https://doi.org/10.1177/1052562906298445

Wisneski, J. E. (2013). So, you want to be a business professor? Business Horizons, 56(5), 551-559. https://doi.org/10.1016/j.bushor.2013.04.007

Wlodkowski, R. J., \& Ginsberg, M. B. (2017). Enhancing adult motivation to learn: A comprehensive guide for teaching all adults. John Wiley \& Sons.

Yin, R. K. (2011). Qualitative Research from Start to Finish. New York: The Guilford Press. 


\section{Copyrights}

Copyright for this article is retained by the author, with first publication rights granted to the journal.

This is an open-access article distributed under the terms and conditions of the Creative Commons Attribution license (http://creativecommons.org/licenses/by/4.0/). 